\title{
Parental Knowledge of Malnutrition as a Cause of Infant and Child Mortality Rate in Torbu Community, Sierra Leone
}

\author{
Alieu Tommy 1,*, Taha Hussein Musa ${ }^{2,3}$, Joseph Kawuki ${ }^{4}$, Upama Ghimire ${ }^{4}$, Nathan Obore ${ }^{4}$, \\ Shireen Salome Papabathini ${ }^{4}$ and Lovel Fornah ${ }^{4}$
}

\author{
${ }^{1}$ Health Education Division, Ministry of Health and Sanitation, New England Ville, Central Medical Stores, \\ Sierra Leone \\ ${ }^{2}$ Biomedical Research Institute, Darfur College, Nyala, Sudan \\ ${ }^{3}$ Key Laboratory of Environmental Medicine Engineering, Department of Epidemiology and Health Statistics, \\ Ministry of Education, School of Public Health, Southeast University, Nanjing, 210009, Jiangsu Province, \\ China \\ ${ }^{4}$ Key Laboratory of Environmental Medicine Engineering, Ministry of Education, Global Health School of \\ Public Health, Southeast University, Nanjing, 210009, Jiangsu Province, China
}

\begin{abstract}
Malnutrition is a significant public health problem over the world, with severe impact in developing countries, including Asia and Africa. This paper present to assess malnutrition as a cause of infant and child mortality rate in Torbu community in Bo city, Sierra Leone. We used a community-based cross-sectional survey. A total of 80 mothers with children of under five years were selected using convenience sampling from the different divisions of Bo city. The findings showed that $48(60 \%)$ of the respondents have never been sensitized nor have any knowledge about Malnutrition, of which $16(50 \%)$ were informed via radio while $50(63 \%)$ were not aware of any nutrition facility around the community. Besides, $56(70 \%)$ of the respondents did not practice exclusive breastfeeding, $64(80 \%)$ fed their children on only carbohydrates mainly in the form of rice, and $26(32.5 \%)$ had one meal per day. $64(80 \%)$ reported their children to have been admitted due to malnutrition (with mainly protein-energy malnutrition), while over a half $46(57 \%)$ reported having lost a child to malnutrition. Thus, we recommended more nutrition education to address the poor Infant and Young Child Feeding (IYCF) practices as well as targeted health interventions to mitigate the devastating effects of child malnutrition in the district.
\end{abstract}

Keywords: Parental knowledge, Malnutrition, Child mortality, Bo city.

\section{INTRODUCTION}

Child malnutrition remains a significant public health problem in African regions [1]. It is the most common cause of mortality and morbidity in children with nearly 3.1 million child deaths annually [2]. Child malnutrition is a single proximate cause of mortality in many countries [3], accounting for approximately $45 \%$ of child deaths globally [4].

A high proportion of malnourished children live in Africa and parts of Asia region. In 2017, UNICEF reported that wasting continued to threaten 50.5 million children under five globally [5]. Worldwide, 149 million children below five years of age were affected with stunted in 2019 , of which 50 million were wasted $[6,7]$.

In previous studies, child health and nutrition's status was associated with many factors such as parental education, access to health services, breastfeeding, and income situation of families [8].

*Address correspondence to this author at the Health Education Division, Ministry of Health and Sanitation, New England Ville, Central Medical Stores, Sierra Leone; Tel: +23275435035; E-mail: alieuktommy15@gmail.com
According to the earlier published reports, child mortality is determined by a combination of biological, environmental, behavioural, and socioeconomic factors [9]. Nutrient adequacy is most commonly evaluated in terms of child growth and development [10].

Knowledge towards child nutrition and mothers breastfeeding infant within 1 hour of birth and continuing for at least two years is essential for infant survival. Besides, it also provides adequate nutrition for the neonate, safe and age-appropriate solid nutrients, and it reduces overall neonatal mortality and by extension, under-five mortality [10]. Therefore, effective breastfeeding or exclusive formula-feeding are required during the 12 weeks of life [11], where most health interventions are required for children during the first two years of life [12].

Sierra Leone experiences a malnutrition burden among its under-five population. As of 2013, the national prevalence of under-five overweight is $8.8 \%$, which has decreased slightly from $9.4 \%$ in 2010 . The national prevalence of under-five stunting is $37.8 \%$, which is greater than the developing country average of $25 \%$. Sierra Leone's under-five wasting prevalence of 
$9.5 \%$ is also higher than the developing country average of $8.9 \%$. In Sierra Leone, $47.2 \%$ of infants under six months are exclusively breastfed; this is well above the Western Africa average of $30.8 \%$. The country's 2015 low birth weight prevalence of $14.4 \%$ has decreased slightly from $17.2 \%$ in 2000 [1].

Despite the general decrease in the prevalence of undernutrition, a considerable number of children below five years still die mainly due to preventable poor IYCF practices in particularly Sierra Leone. The study thus aimed to assess malnutrition as a cause of infant and child mortality rate in Torbu community, Bo City, Sierra Leone.

\section{MATERIALS AND METHODS}

\section{Study Design}

This was a descriptive cross-sectional communitybased study conducted between the periods of August 2015 to December 2015.

\section{Study Area}

The study was carried out in Bo district, the secondlargest city in Sierra Leone, the largest city in the Southern Province by geographical location (Figure 1). The city is located in Southern Province of Sierra Leone, and It is the second-most populous district in Sierra Leone with an estimated population over 175,000 , based on the 2015 national census. Bo district is an urban centre and lies approximately 160 miles east south-east of Freetown and about 44 miles to Kenema.

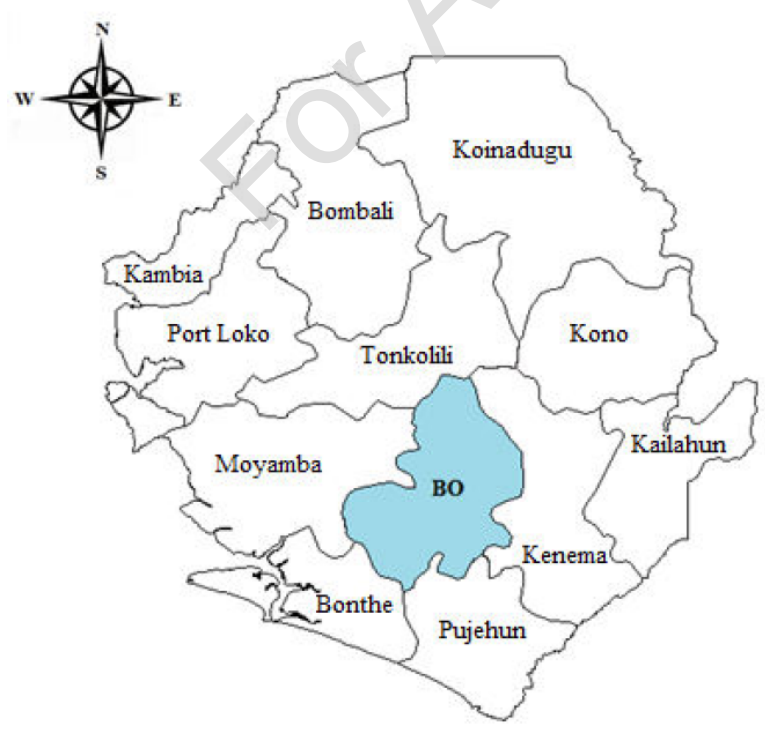

Figure 1: Geographic location of Bo District, Southern Province of Sierra Leone.

\section{Sample Selection and Populations}

The study population were selected for Bo city, the most affected area by malnutrition. The total of 80 mothers with children below five years was collected from the household of Torbu community, a slum area in Bo city. Due to the limited resources and critical health status for the region, we used a convenience sampling method to assess malnutrition as a cause of infant and child mortality rate in Torbu community, Bo city, by using structured questionnaire and face to face interview. The questionnaire was first pretested for its validity and relevance.

\section{Statistical Analysis}

The collected data were analysed by SPSS (v. 22.0, Chicago, Illinois, USA) and was used to conduct the statistical analyses. Percentage and frequency distribution were calculated for study parameters.

\section{Ethical Approval}

A letter of permission was collected from the Department of Environmental Health Sciences Njala University Bo Campus. The local authorities provided permission for collecting the data at the household level. Informed consent was obtained from the parents after explaining the purpose of the study. Confidentiality was assured to all informants, and their anonymity was guaranteed as no nomenclature or identification of the parent or study participant child was collected during the interview.

\section{RESULTS}

\section{Demographic Distribution of Respondents}

The respondent's age ranged from 13 to $\geq 31$ years. The majority of mothers were married $48(60 \%), 14$ (17.5) Divorced, 10 (12.5\%) were widows, and 8 (10\%) were single. Most of the respondents of Temne tribe 38 $(47.5 \%), 24(30 \%)$ were Mende, and few were other tribes. Over half of the respondents, $68(85 \%)$ were Muslims, and only a few $12(15 \%)$ were Christians. Out of these, $62(77.5 \%)$ were illiterate, $9(11.2 \%)$ stopped at the secondary school level, $7(8.8 \%)$ primary level of education and $2(2.5 \%)$ did voluntary tertiary. Majority of the investigated respondents are doing petty trading as their occupation $56(70 \%), 18(22.5 \%)$ are doing farming/gardening, $4(5 \%)$ and $2(2.5 \%)$ are teachers and health workers respectively. Most mothers have 56 children $38(47.5 \%), 20(25 \%)$ have above 6 children, 
$16(20 \%)$ have $3-4$ children and $6(7.5 \%)$ have $1-2$ children (Table 1).

Table 1: Demographic distribution of Respondents $(\mathrm{N}=\mathbf{8 0})$

\begin{tabular}{|c|c|c|}
\hline \multicolumn{2}{|c|}{ Study variable } & \multirow{2}{*}{$\begin{array}{c}\text { Frequency (\%) } \\
11(13.8)\end{array}$} \\
\hline Age & $13-18$ & \\
\hline & $19-24$ & $13(16.2)$ \\
\hline & $25-30$ & $20(25)$ \\
\hline & Above 30 & $36(45)$ \\
\hline \multirow[t]{4}{*}{ Marital Status } & Single & $8(10)$ \\
\hline & Married & $48(60)$ \\
\hline & Divorced & $14(17.5)$ \\
\hline & Widow & $10(12.5)$ \\
\hline \multirow[t]{5}{*}{ Ethic Group } & Sherbro & $4(5)$ \\
\hline & Limba & $8(10)$ \\
\hline & Temne & $38(47.5)$ \\
\hline & Mende & $24(30)$ \\
\hline & Others & $6(7.5)$ \\
\hline \multirow[t]{2}{*}{ Religion } & Muslim & $68(85)$ \\
\hline & Christian & $12(15)$ \\
\hline \multirow[t]{4}{*}{ Educational Level } & Primary & $7(8.8)$ \\
\hline & Secondary & $9(11.2)$ \\
\hline & Voluntary/Tertiary & $2(2.5)$ \\
\hline & Illiterate & $62(77.5)$ \\
\hline \multirow[t]{4}{*}{ Occupation } & Petty Trading & $56(70)$ \\
\hline & Farming/gardening & $18(22.5)$ \\
\hline & Teacher & $4(5)$ \\
\hline & Health Worker & $2(2.5)$ \\
\hline \multirow[t]{4}{*}{ Number of Children } & $1-2$ & $6(7.5)$ \\
\hline & $3-4$ & $16(20)$ \\
\hline & $5-6$ & $38(47.5)$ \\
\hline & Above 6 & $20(25)$ \\
\hline
\end{tabular}

\section{Knowledge about Malnutrition among Respondents}

Out of the 80 mothers, $32(40 \%)$ of them confirmed to have been sensitized on malnutrition and $48(60 \%)$ of them have never been sensitised. Of the $32(40 \%)$ sensitised, $16(50 \%)$ of the respondents were sensitised through the medium of radio, $8(25 \%)$ hospital/clinic, $5(15.6 \%)$ community and $3(9.4 \%)$ in other ways. $30(37 \%)$ of the respondents know of a malnutrition facility, and 50 ( $63 \%$ ) of them did not know of any malnutrition facility. Out of the $30(37 \%)$ that know of a malnutrition facility, $12(40 \%)$ of them said they did weight for height service, $9(30 \%)$ mid-upper arm circumference (MUAC) service, $6(20 \%)$ supplementary feeding service and $3(10 \%)$ of them refer if the case is severe. From those that have adequate knowledge of malnutrition facility $4(13.3 \%)$, of them said they have no proper facility $8(2.67 \%)$, and partially effective $12(40 \%)$. Out of the 30 respondents that know of malnutrition facility, $6(20 \%)$ said the reception is hasty, $9(30 \%)$ is encouraging, and 15 $(50 \%)$ said the reception is average (Table 2 ).

Table 2: Knowledge about Malnutrition among Respondents

\begin{tabular}{|c|c|}
\hline Variables & Frequency $(\%)$ \\
\hline \multicolumn{2}{|c|}{ Have you at any time been sensitised on malnutrition? } \\
\hline Yes & $32(40)$ \\
\hline No & $48(60)$ \\
\hline \multicolumn{2}{|l|}{ If Yes, means of sensitisation } \\
\hline Radio & $16(50)$ \\
\hline Hospital/Clinic & $8(25)$ \\
\hline Community & $5(15.6)$ \\
\hline Others & $3(9.4)$ \\
\hline
\end{tabular}

Do you know of any facility in your locality where malnutrition issues are dealt with?

\begin{tabular}{|c|c|}
\hline Yes & $30(37)$ \\
\hline No & $50(63)$ \\
\hline \multicolumn{2}{|l|}{ If yes, what are the services carried out there } \\
\hline They do weight for height & $12(40)$ \\
\hline $\begin{array}{l}\text { They do mid upper arm circumference } \\
\text { (MUAC) }\end{array}$ & $9(30)$ \\
\hline Supplementary feeding & $6(20)$ \\
\hline Refer, if malnutrition condition is severe & $3(10)$ \\
\hline \multicolumn{2}{|l|}{ How do you rate the effectiveness of that facility } \\
\hline Effective & $4(13.3)$ \\
\hline Not effective & $8(26.7)$ \\
\hline Partially effective & $12(40)$ \\
\hline Others & $6(20)$ \\
\hline \multicolumn{2}{|l|}{ Reception of staff in that facility } \\
\hline Hastily & $6(20)$ \\
\hline Encouraging & $9(30)$ \\
\hline Average & $15(50)$ \\
\hline
\end{tabular}

\section{Household Food Security and Practice by Respondents}

Based on household heads, $48(60 \%)$ of them said their husband/partner is the breadwinner of the house, 
$24(30 \%)$ are themselves, and $8(10 \%)$ are other people. In terms of food preparation, $64(80 \%)$ of them eat carbohydrates, $8(10 \%)$ eat protein only, $6(7.5 \%)$

Table 3: Household Food Security and Practices of the Respondents

\begin{tabular}{|c|c|}
\hline Variables & Frequency $(\%)$ \\
\hline \multicolumn{2}{|l|}{ Who is the breadwinner of the house } \\
\hline Husband/ partner & $48(60)$ \\
\hline Self & $24(30)$ \\
\hline Others & $8(10)$ \\
\hline \multicolumn{2}{|c|}{ What type of food do you normally prepare as meal } \\
\hline Carbohydrate only & $64(80)$ \\
\hline Proteins only & $8(10)$ \\
\hline Proteins, Carbohydrate and vitamins & $6(7.5)$ \\
\hline Others & $2(2.5)$ \\
\hline \multicolumn{2}{|c|}{ Number of meals available in the household per day } \\
\hline Once & $26(32.5)$ \\
\hline Twice & $24(30)$ \\
\hline Thrice & $8(10)$ \\
\hline Irregular & $22(27.5)$ \\
\hline \multicolumn{2}{|c|}{ What food do you usually give as weaning food } \\
\hline Rice & $64(80)$ \\
\hline Milk & $12(15)$ \\
\hline Others & $4(5)$ \\
\hline \multicolumn{2}{|c|}{ Do you ultimately carry exclusive breastfeeding? } \\
\hline Yes & $24(30)$ \\
\hline No & $56(70)$ \\
\hline \multicolumn{2}{|c|}{ For how long you breastfeed your children (Month) } \\
\hline $0-6$ & $6(7.5)$ \\
\hline $7-12$ & $24(30)$ \\
\hline $13-18$ & $18(22.5)$ \\
\hline $19-24$ & $22(27.5)$ \\
\hline Above 24 & $10(12.5)$ \\
\hline \multicolumn{2}{|c|}{ Do you normally give egg or meat to your children } \\
\hline Yes & $8(10)$ \\
\hline No & $72(90)$ \\
\hline \multicolumn{2}{|l|}{ If yes, how often per day } \\
\hline Irregular & $6(66.7)$ \\
\hline Twice & $0(0)$ \\
\hline Thrice & $2(33.3)$ \\
\hline \multicolumn{2}{|l|}{ If no, what's the reason } \\
\hline Cannot afford & $48(66.7)$ \\
\hline Cultural reasons & $24(33,3)$ \\
\hline
\end{tabular}

eat protein, carbohydrates, vitamins and $2(2.5 \%)$ eat other foods. More than quarter 26 ( $32.5 \%$ ) of mothers had one meal per day, $24(30 \%)$ had two meals per day, $8(10 \%)$ had three meals per day and $22(27.5 \%)$ had irregular meal per day.

Majority of mothers $64(80 \%)$ give rice to their children as weaning food, $12(15 \%)$ give milk, and $4(5 \%)$ give other food as weaning food. Only $24(30 \%)$ of mothers carry out exclusive breastfeeding, and 56 $(70 \%)$ did not carry out exclusive breastfeeding. 6 $(7.5 \%)$ of mothers breastfeed their children between the periods of $0-6$ months, $24(30 \%)$ between $7-12$ months, $18(22.5 \%)$ between $13-18$ months, $22(27.5 \%)$ between $19-24$ months and $10(12.5 \%)$ above 24 months. From food given, $8(10 \%)$ usually give egg/meat to older children and $72(90 \%)$ of them did not provide egg/meat to older children. Of the $8(10 \%)$ mothers that usually gave egg/meat to older children, $6(66.7 \%)$ give egg/meat irregularly per day, and $2(33.3 \%)$ give egg/meat thrice per day. Of the $72(90 \%)$ respondents that did not usually give egg/meat to older children, 48 $(66.7 \%)$ said they could not afford to buy it, and 24 $(33.3 \%)$ is because of cultural reasons (Table 3 ).

\section{Disease Frequency on Malnutrition}

Majority of mothers $64(80 \%)$ said their child has ever been admitted and $16(20 \%)$ said their child has never been admitted as a result of food disorder/ malnutrition. Of the $64(80 \%)$ that their child has been admitted as a result of food disorder/malnutrition, 1 $(1.6 \%)$ said was obesity, $10(15.6 \%)$ was marasmus, $20(31.3 \%)$ was kwashiorkor, and $33(51.5 \%)$ was due to protein-energy malnutrition. More than half of mothers reported that $46(57 \%)$ of their child had died of food disorder/malnutrition and $34(43 \%)$ said their child had never died of food disorder/malnutrition. Out of $46(57 \%)$ that reported their child/children had died of food disorder/malnutrition, $18(39.1 \%)$ of them said only one child has died, $16(34.8 \%)$ said two children have died, $10(21.7 \%)$ said three children have died, and $2(4.4 \%)$ said above 3 children have died. Of the $46(57 \%)$ respondents that said their child/children had died of food disorder, $3(6.5 \%)$ said they died within $0-6$ months, $5(10.9 \%)$ died within 7-12 months, $6(13 \%)$ died within 13-18 months, 12 (26.1\%) died within 19-24 months and 20 (43.5\%) died above 24 months (Table 4).

\section{DISCUSSION}

Most of the respondents were above 30 years, with over half of them were married, and the majority of 
ethnicity were the Temne's. Religion was also another attribute that was investigated among respondents in which the majority was Muslims. Most of the mothers were illiterate, and the majority of them embark on petty trading as their occupation showing that it was a market area dominated study.

Table 4: Disease frequency due to Malnutrition

\begin{tabular}{|c|c|}
\hline Variables & $\begin{array}{l}\text { Frequency } \\
\quad(\%)\end{array}$ \\
\hline \multicolumn{2}{|c|}{$\begin{array}{l}\text { Have any of your children been admitted as result of food disorder } \\
\text { / malnutrition }\end{array}$} \\
\hline Yes & $64(80)$ \\
\hline No & $16(20)$ \\
\hline \multicolumn{2}{|l|}{ If yes, indicate the type(s) of food disorder } \\
\hline Obesity & $1(1.6)$ \\
\hline Marasmus & $10(15.6)$ \\
\hline Kwashiorkor & $20(31.3)$ \\
\hline Protein energy malnutrition & $33(51.5)$ \\
\hline \multicolumn{2}{|c|}{ Have any of your children died of food disorder / malnutrition? } \\
\hline Yes & $46(57)$ \\
\hline No & $34(43)$ \\
\hline \multicolumn{2}{|l|}{ If yes, at what age? } \\
\hline $0-6$ months & $3(6.5)$ \\
\hline 7-12 months & $5(10.9)$ \\
\hline $13-18$ months & $6(13)$ \\
\hline 19-24 months & $12(26.1)$ \\
\hline Above 24 months & $20(43.5)$ \\
\hline \multicolumn{2}{|c|}{ Number of children died from food disorder } \\
\hline One & $18(39.1)$ \\
\hline Two & $16(34.8)$ \\
\hline Three & $10(21.7)$ \\
\hline Above 3 & $2(4.4)$ \\
\hline
\end{tabular}

The study assessed the number of children in the household is as high as 5-6 children. The size of the household determines resource allocation including food, as supported by previous studies which have revealed a significant association between the number of children in the family and the children's nutrition status $[13,14]$.

Majority of the mothers did not know nor been sensitised on malnutrition, yet mothers/ caretakers' play a vital role in preventing child malnutrition. This is supported by Amsalu and Tigabu's study, which showed that "underweight was significantly associated with the parent level of education on malnutrition" [15].
Out of those that knew, the most common source of information was radio, which implies the radio could be the most appropriate media for mass nutrition sensitisation.

Most respondents were found not to know about any malnutrition facility. For those that know about the facility, most said they do weight for height service. Reviewing the effectiveness of the facility, the majority said the facility is not effective. Considering the reception of the facility, staffs are at average in terms of reception. This highlights the gaps in nutrition servicedelivery that need to be addressed.

Most mothers reported that the father is the breadwinner of the households, yet most of them had ever had one of their malnourished. This is opposite to the Nnyepi et al. findings which showed that "children who are raised by guardians (brother, sister, uncle, aunt, or other relative besides the biological mother) had a greater risk of malnutrition than children raised by their biological mothers" [16]. The study noted carbohydrates as the most fed food for children compared to proteins and other foods. This is a bad feeding practice, since children need more of the proteins to support tissue and organ development, as supported by current evidence $[13,17]$.

Most respondents had an only meal a day and did not give egg/meat to their children, this implying inadequate food access, as most of the households cannot afford nutritious foods. This is mainly due to parents' unemployment which in turn has led to household food insecurity and insufficient access to food. This directly affects nutrient intake, increasing the risk of severe malnutrition among children [17, 18]. The study revealed that majority of mothers did not carry out exclusive breastfeeding and gave rice as weaning food to their children. This as well affects the nutritional adequacy among infants, as exclusive breastfeeding is the only complete food for infants below six months, after which complementary feeding should be initiated $[19,20]$.

The study found that most of the children had been admitted as a result of food disorder/ malnutrition inadequate nutrition due to poor feeding practices compromises the children's immunity to defend against diseases, as supported by previous studies [21, 22]. Protein-energy malnutrition is the most common nutrition-related complication that children are admitted for. This due to the noted poor feeding practices coupled with other childhood diseases, both rendering 
children to severe acute malnutrition [18, 23]. The study also noted high mortality due to malnutrition, and this is in line with UNICEF, which highlights malnutrition as a leading cause of under-five mortality in developing countries [7, 23]. This calls for a target response to address malnutrition and its effects [24, 25] if the UN's Sustainable Development Goal of "Zero hunger" is to be achieved.

The current study had limitations; for example; it used a small sample size which affects the representativeness and reliability of the results. Therefore similar research should be conducted on a large sample of under-five children to detect the effects of some of the factors that could not be assessed by the current study.

The results of this study indicate that child malnutrition in Torbu community, Bo City is multifaceted and requires multi-sectoral, multidisciplinary and multi-level action to alleviate it. This study has discovered that there are basic, underlying and immediate causes that act at various levels of society and which contribute to the occurrence of child malnutrition and mortality in Torbu community, Bo City. There is a need for targeted health and nutrition education as well as sensitisation to address the poor IYCF practices among the mothers in the region. In addition, there is a need to improve the livelihoods of families to improve access to nutritious foods and other health resources. The implication for Public Health is that more research should be undertaken on this topic in Sierra Leone.

\section{ACKNOWLEDGEMENT}

I would like to acknowledge the cooperative's of a classmate and community workers, families for their contribution in this study.

\section{CONFLICT OF INTEREST}

None.

\section{REFERENCES}

[1] UNICEF global databases Infant and Young Child Feeding, UNICEF/WHO/World Bank Group: Joint child malnutrition estimates, UNICEF/WHO Low birthweight estimates, NCD Risk Factor Collaboration, WHO Global Health Observatory. Available from: https://www.who.int/nutgrowthdb/en/.

[2] Vaivada T, Gaffey MF, Das JK, Bhutta ZA. Evidence-based interventions for improvement of maternal and child nutrition in low-income settings: what's new?. Current Opinion in Clinical Nutrition and Metabolic Care 2017; 20(3): 204-10. https://doi.org/10.1097/MC0.0000000000000365
[3] Rice AL, Sacco L, Hyder A, Black RE. Malnutrition as an underlying cause of childhood deaths associated with infectious diseases in developing countries. Bulletin of the World Health Organization 2000; 78: 1207-21.

[4] Odjidja EN, Hakizimana S. Data on acute malnutrition and mortality among under-5 children of pastoralists in a humanitarian setting: a cross-sectional Standardized Monitoring and Assessment of Relief and Transitions Study. BMC Research Notes 2019; 12(1): 434 https://doi.org/10.1186/s13104-019-4475-x

[5] UNICEF, WHO, and World Bank, "Levels and Trends in Child malnutrition," 2018. Available from: https://www.un.org/en/ development/desa/population/publications/mortality/childmortality-report-2018.asp.

[6] World Health Organization. World health statistics 2019: monitoring health for the SDGs, sustainable development goals. Available from: https://apps.who.int/iris/bitstream/ handle/10665/324835/9789241565707-eng.pdf.

[7] UNICEF 2019. The State of the World's Children, 2019. Available from: https://www.unicef.org/reports/state-ofworlds-children-2019.

[8] Tarekegn SM, Lieberman LS, Giedraitis V. Determinants of maternal health service utilization in Ethiopia: analysis of the 2011 Ethiopian Demographic and Health Survey. BMC Pregnancy and Childbirth 2014; 14(1): 161. https://doi.org/10.1186/1471-2393-14-161

[9] Mosley $\mathrm{WH}$, Chen LC. An analytical framework for the study of child survival in developing countries. Bulletin of the World Health Organization 2003; 81: 140-5.

[10] Butte NF, Lopez-Alarcon MG, Garza C. Nutrient adequacy of exclusive breastfeeding for the term infant during the first six months of life. World Health Organization 2002.

[11] ljumba P, Doherty T, Jackson D, Tomlinson M, Sanders D, Swanevelder S, Persson LA. Effect of an integrated community-based package for maternal and newborn care on feeding patterns during the first 12 weeks of life: a clusterrandomized trial in a South African township. Public health Nutrition 2015; 18(14): 2660-8.

https://doi.org/10.1017/S1368980015000099

[12] Black RE, Victora CG, Walker SP, Bhutta ZA, Christian P, De Onis M, Ezzati M, Grantham-McGregor S, Katz J, Martorell $\mathrm{R}$, Uauy R. Maternal and child undernutrition and overweight in low-income and middle-income countries. The Lancet 2013; 382(9890): 427-51. https://doi.org/10.1016/S0140-6736(13)60937-X

[13] Joseph K, Musa TH, Pherry O. Dietary practices, WASH conditions, and disease occurrence among children below five years in households of Nangabo, Wakiso district, Uganda. Scientific African 2020; 25: e00291. https://doi.org/10.1016/j.sciaf.2020.e00291

[14] Hoa NN, Hien NN. Nutritional Status and Determinants of Malnutrition in Children under Three Years of Age in Nghean, Vietnam.

[15] Amsalu S, Tigabu Z. Risk factors for severe acute malnutrition in children under the age of five: a case control study. Gondar, Ethiopia: Ethiop. J Health Dev 2008; 22(1). https://doi.org/10.4314/ejhd.v22i1.10058

[16] Nnyepi M, Mmopelwa D, Codjia P. Child nutrition and household economic situation in the context of rising food prices in Mabutsane and Bobirwa (in Maundeni T. P (Ed). Thari ya Bana: Reflections on Children in Botswana in Gaborone, Botswana: UB and UNICEF) 2010.

[17] Schwinger C, Golden MH, Grellety E, Roberfroid D, Guesdon B. Severe acute malnutrition and mortality in children in the community: Comparison of indicators in a multi-country pooled analysis. PloS One 2019; 14(8).

\section{https://doi.org/10.1371/journal.pone.0219745}

[18] Turyashemererwa FM, Kikafunda JK, Agaba E. Prevalence of early childhood malnutrition and influencing factors in peri 
urban areas of Kabarole district, western Uganda. African Journal of Food, Agriculture, Nutrition and Development 2009; 9(4) https://doi.org/10.4314/ajfand.v9i4.43872

[19] Mahgoub SEO, Nnyepi M, Bandeke T. Factors affecting prevalence of malnutrition among children under three years of age in Botswana. African Journal of Food, Agriculture, Nutrition and Development 2006; 6: 1-15. https://doi.org/10.4314/ajfand.v6i1.19171

[20] Roba KT, O'Connor TP, Belachew T, O'Brien NM. Infant and young child feeding (IYCF) practices among mothers of children aged 6-23 months in two agro-ecological zones of rural Ethiopia. Int J Nutr Food Sci 2016; 5(3): 185-94. https://doi.org/10.11648/j.jinfs.20160503.16

[21] Müller O, Krawinkel M. Malnutrition and health in developing countries. CMAJ 2005; 173(3): 279-86. https://doi.org/10.1503/cmaj.050342

[22] Adebisi YA, Ibrahim K, Lucero-Prisno III DE, Ekpenyong A, Micheal AI, Chinemelum IG, Sina-Odunsi AB. Prevalence and Socio-economic Impacts of Malnutrition Among Children in Uganda. Nutrition and Metabolic Insights 2019. https://doi.org/10.1177/1178638819887398

[23] Gebre A, Reddy PS, Mulugeta A, Sedik Y, Kahssay M. Prevalence of malnutrition and associated factors among under-five children in pastoral communities of afar regional state, Northeast Ethiopia: A community-based crosssectional study. Journal of Nutrition and Metabolism 2019; 2019.

https://doi.org/10.1155/2019/9187609

[24] Caulfield LE, de Onis M, Blössner M, Black RE. Undernutrition as an underlying cause of child deaths associated with diarrhea, pneumonia, malaria, and measles. The American Journal of Clinical Nutrition 2004 1; 80(1): 1938. https://doi.org/10.1093/ajen/80.1.193

[25] Musa Taha H, Musa Hassan H, Ali Elrasheed A, Musa Nazik E. Prevalence of malnutrition among children under five years old in Khartoum State, Sudan. Polish Ann Med 2014 https://doi.org/10.1016/j.poamed.2014.01.001 